\title{
Post-challenge immune gene expression profiling in rohu, Labeo rohita vaccinated with modified adjuvant-based Aeromonas hydrophila outer membrane protein $\mathbf{R}$ formulation
}

\author{
Pujarini Dash', Sunita K. Yadav², Lalit C. Garg³, Aparna Dixit², \\ and Pramoda K. Sahoo ${ }^{1 *}$ \\ ${ }^{I}$ Central Institute of Freshwater Aquaculture, Kausalyaganga, Bhubaneswar, India \\ ${ }^{2}$ Gene Regulation Laboratory, School of Biotechnology, Jawaharlal Nehru University, New Delhi, India \\ ${ }^{3}$ Gene Regulation Laboratory, National Institute of Immunology, Aruna Asaf Ali Marg, New Delhi, India
}

\begin{abstract}
DASH, P., S. K. YADAV, L. C. GARG, A. DIXIT, P. K. SAHOO: Post-challenge immune gene expression profiling in rohu, Labeo rohita vaccinated with modified adjuvant-based Aeromonas hydrophila outer membrane protein $\mathbf{R}$ formulation. Vet. arhiv 87, 607-622, 2017.
\end{abstract}

ABSTRACT

Although vaccination and post-vaccination studies have gained considerable importance in the field of aquaculture diseases, little is understood about the mechanism of immune-protection in vaccinated fish following infection. In the present study, an attempt was made to discover the mechanism of protection rendered by a modified adjuvant-based recombinant outer membrane protein $\mathrm{R}(\mathrm{rOmpR})$ vaccine, in rohu, Labeo rohita (an important Indian major carp species) following a challenge with Aeromonas hydrophila. For this, expression analysis of an array of immune molecules (IgM, complement factor 3, interleukin $1 \beta$, interleukin 6 , tumor necrosis factor $\alpha$, interleukin 15 , MHC I and MHC II) was carried out in the anterior kidney tissues of vaccinated fish, at $0,12,24,48,72$ and $120 \mathrm{~h}$ post-challenge. Higher transcript levels of IgM, MHC I and MHC II were evident in the mineral oil-based OmpR vaccinated and modified adjuvant-based OmpR-vaccinated groups, at different time points post-challenge, including the non-challenged fish. Early onset of pro-inflammatory cytokines and expression of most of the immune genes was more pronounced in vaccinated fish at different time points post-challenge, thus indicating a better immune response in these fish. This study indicated the activation of both humoral and cell mediated immunity in vaccinated rohu following a challenge with $A$. hydrophila.

Key words: adjuvant, Aeromonas hydrophila, gene expression, post-challenge, Labeo rohita

\footnotetext{
*Corresponding author:

Pramoda K. Sahoo, Central Institute of Freshwater Aquaculture, Kausalyaganga, Bhubaneswar 751002, India, Fax: +91 674 2465 407; E-mail: pksahoo1@hotmail.com
} 


\section{P. Dash et al.: Post-challenge immune response in rOmpR vaccinated rohu}

\section{Introduction}

Vaccination is considered to be the most effective strategy to combat bacterial diseases in aquaculture. Currently, a number of commercialized vaccines are available against various fish pathogens, with different degrees of success. Though these vaccines provide immune-protection against particular pathogens, the exact mechanism is not known. Vaccines are expected to produce memory cells for long periods, whereas higher levels of antibody production are correlated with vaccine efficacy (YANG et al., 2013). In addition to antibodies, cellular immune molecules are also considered to mediate protective immunity (YANG et al., 2013). A number of investigations have been carried out to evaluate the post-administration effect of vaccines in different species of fish. However, it is essential to understand the protective immune response in vaccinated fish after infection with a particular pathogen, in order to further enhance the efficacy of a vaccine. Stimulation of antigen presenting molecules, viz. major histocompatibility complex I and II in vaccinated fish, as well as after infection has been reported (YANG et al., 2013). Induction of adaptive immunity in vaccinated rainbow trout after infection with a wild type Yersinia ruckeri illustrates the role of adaptive immune response in vaccine induced immunity (HARUN et al., 2011). On the other hand, no correlation was found with an increase in the expression of genes involved in specific immunity in response to viral haemorrhagic septicaemia virus in DNA-vaccinated rainbow trout, and involvement of memory cells was thought to play a role in stimulating host immunity (CUESTA and TAFALLA, 2009). As far as the quantity and cost effectivity of vaccines are concerned, recombinant vaccines have been proved to be one of the best alternatives (POOBALANE et al., 2010). In addition to vaccines, adjuvants play an important role in induction of stronger immune response. Although mineral oil (MO) is a widely used adjuvant in aquaculture, its use poses a risk due to its undesirable side effects (POPPE and BRECK, 1997). However, plant extracts, when used as adjuvants against Aeromonas hydrophila, have been reported to stimulate immune response as well as increase the survival rate in several species of fish (YIN et al., 2009). Developing a vaccine against this pathogen remains a challenge as its pathogenesis is multifactorial. Earlier studies from our laboratory reported evaluation of a modified adjuvant, while conducting vaccination studies in $L$. rohita with a recombinant outer membrane protein $\mathrm{R}$ (rOmpR) of $A$. hydrophila. The modified adjuvant consisted of a combination of the widely used mineral oil and a herbal product, and was found to reduce the side effects of the mineral oil. The modified adjuvant, when used with the rOmpR, resulted in an enhanced immune response against the $\mathrm{rOmpR}$ of $A$. hydrophila, and reduced mortality significantly upon $A$. hydrophila challenge (DASH et al., 2014). In the present study, we attempted to explore the resistance mechanism in L. rohita, immunized with the modified adjuvant-based rOmpR vaccine and subsequently challenged with virulent $A$. hydrophila. 


\section{P. Dash et al.: Post-challenge immune response in rOmpR vaccinated rohu}

Expression analysis of immune genes in naïve fish during infection or in vaccinated fish following challenge has always been of interest in the field of infection and immunity. Pro-inflammatory cytokines were found to be induced in the anterior kidney of Puntius sarana during initial periods of infection with $A$. hydrophila (DAS et al., 2011). An increase in the expression of TNF- $\alpha$ and IL- 8 has been reported in Zebrafish, vaccinated with a mutated strain of $E$. tarda (WED: a live attenuated strain of $E$. tarda) at early periods postchallenge. The MHC I mediated pathway has been reported to play a role in protection during E. tarda infection in a mutant E. tarda vaccinated zebra fish (YANG et al., 2013). Although the role of C3 in antibacterial immunity is well documented, the initiator of the complement cascade has rarely been studied in vaccinated fish (ZHOU et al., 2008).

In the present study, we carried out expression profiling of an array of immune-related genes of the antigen presentation pathway \{major histocompatibility complex I and II (MHC I and MHC II)\}, cytokine cascade \{interleukin-1 $\beta$ (IL-1 $\beta$ ), interleukin-6 (IL-6), interleukin-15 (IL-15) and tumor necrosis factor (factor- $\alpha$ (TNF- $\alpha$ ) $\}$, the complement system \{complement factor $3(\mathrm{C} 3)\}$ and antibody-mediated response (IgM), in order to understand the mechanism of protection, upon $A$. hydrophila challenge in fish immunized with a vaccine formulation of rOmpR and a modified adjuvant. Since the anterior kidney is an important lymphoid organ in fish that houses various types of immune cells and is one of the target organs of acute septicemia during A. hydrophila infection, gene expression studies were conducted in this tissue.

\section{Materials and methods}

Experimental design. Rohu (L. rohita) juveniles (healthy, without prior history of any infection, average weight $70.0 \pm 5.2 \mathrm{~g}$ ), were received from the farm of the Central Institute of Freshwater Aquaculture (CIFA), Bhubaneswar, India. Animals were kept for 15 days for acclimatization in fiber-reinforced plastic tanks of 1,200 L capacity in dechlorinated tap water, before conducting the experiment. A commercial pellet diet (ABIS floating feed, Indian Solvent Industry, India), at $2.5 \%$ of body weight, was fed to the fish in two divided doses daily. About one-tenth of the water was siphoned regularly, and the water parameters were measured at regular intervals to maintain optimum water quality. The water temperature ranged from $25-28{ }^{\circ} \mathrm{C}$ throughout the experimental period. The fish were randomly distributed into experimental groups of thirty fish each (in triplicate, 10 fish per tank) under continuous aeration.

Vaccine, adjuvant, bacterial isolate and vaccination protocol. Large scale production of rOmpR was carried out using pRSET.AhOmpR plasmid as per the protocol described previously (DASH et al., 2014). The mineral oil-based herbal modified adjuvant was prepared as described by DASH et al. (2014). The bacterial isolate of $A$. hydrophila (Ah\#15) 


\section{P. Dash et al.: Post-challenge immune response in rOmpR vaccinated rohu}

used in this study was isolated from a dermal ulcer of $L$. rohita during an outbreak, and was preserved in glycerol at $-80{ }^{\circ} \mathrm{C}$ (MOHANTY et al., 2008).

All immunizations were carried out with $0.2 \mathrm{~mL}$ of formulation intraperitoneally. The fish were divided into six groups including a naïve control (group A), a group immunized with PBS and mineral oil (PBS-MO in 1:1) (group B), group C immunized with formalinkilled A. hydrophila (FKC, $10^{6}$ cells/fish) (in PBS with MO), and group D injected with the same bacterial antigen as in group $\mathrm{C}$ with a modified adjuvant. The other two groups - groups E and F received rOmpR (1.5 $\mu \mathrm{g} / \mathrm{g}$ body weight) in PBS and MO, and rOmpR in modified adjuvant formulation, respectively. Two booster doses of a similar amount were administered to all the groups with the respective vehicles on days 21 and 35 postinjection (dpi).

Post-challenge sample collection. At 60 days post-vaccination (dpv), the fish from all the groups were challenged with virulent $A$. hydrophila $\left(10^{7} \mathrm{cfu} / \mathrm{fish}\right)$. Anterior kidney tissues were collected (in triplicate) aseptically in RNAlater (Sigma-Aldrich Chemicals Co., USA) by sacrificing three fish from each group (one from each replicate) at $0 \mathrm{~h}$ (before challenge) and 12, 24, 48, 72 and $120 \mathrm{~h}$ post-challenge, based on our previous observations and earlier reports in channel catfish, regarding the presence of an increased load of bacteria at around $12 \mathrm{~h}$ or thereafter, causing major damage to the anterior kidney. They were kept at $-80{ }^{\circ} \mathrm{C}$ for further study (MAHAPATRA et al., 2008; MU et al., 2011).

The cause of any mortality was ascertained by isolating bacteria from 5 moribund fish and confirmation by PCR using $A$. hydrophila specific primers (MOHANTY et al., 2008).

RNA isolation, $c D N A$ synthesis and $q P C R$. Total RNA was extracted from kidney samples using a TRI reagent (Sigma-Aldrich Chemicals Co., USA) according to the manufacturer's instructions. RNA samples were treated with DNase I to remove DNA contamination. The quality and integrity of RNA were checked using NanoDrop ND1000 (Thermo scientific, USA), and by performing reverse transcript ion PCR with $\beta$-actin primers, respectively. For reverse-transcription PCR, $1 \mu \mathrm{g}$ of total RNA was used to synthesize complementary DNA (cDNA), as described previously (SAHOO et al., 2013). The cDNAs were stored at $0{ }^{\circ} \mathrm{C}$ until further use. For qPCR analysis, $100 \mathrm{ng}$ of cDNA was used and the sample normalization was carried out using the constitutively expressed reference gene $\beta$-actin. Expression levels of IgM, C3, IL-1 $\beta$, IL-6, IL-15, TNF- $\alpha$, MHC I and MHC II were analyzed using either published or self-designed gene specific primers. Primer pairs for C3, IL-6, MHC I and MHC II were designed from the published L. rohita mRNA contig seq whereas primers for IL-1 $\beta$ and IgM were derived from rohu IL-1 $\beta$ (AM932525.1) and IgM (HM58639.1) mRNA sequences available in the NCBI database (Table 1). Purified PCR products of self-designed primers were cloned into the $\mathrm{T}$ cloning vector using an instant cloning kit (Bangalore Genei, Bangalore), and transformed into $E$. 


\section{P. Dash et al.: Post-challenge immune response in rOmpR vaccinated rohu}

coli DH5 $\alpha$ cells. Three positive clones were sequenced, and bioinformatics analysis was carried out for confirmation (data not provided).

Table 1. Primers used with their optimum annealing temperatures and sizes of PCR amplicons

\begin{tabular}{|c|c|c|c|c|}
\hline Gene & Primer sequence (5' to 3 ') & $\begin{array}{c}\text { Optimum } \\
\text { annealing } \\
\text { temperature } \\
\left({ }^{\circ} \mathrm{C}\right)\end{array}$ & $\begin{array}{l}\text { Size of } \\
\text { PCR } \\
\text { amplicon } \\
\text { (bp) }\end{array}$ & Reference \\
\hline $\operatorname{IgM}$ & $\begin{array}{l}\text { F-ACGCTTCACCATCTCCA } \\
\text { R-AGCCACCGTAGCCTCTT }\end{array}$ & 47.6 & 110 & $\begin{array}{l}\text { n.s. (not } \\
\text { submitted), s.d } \\
\text { (self designed) }\end{array}$ \\
\hline $\begin{array}{l}\text { Complement } \\
\text { factor } 3(\mathrm{C} 3)\end{array}$ & $\begin{array}{l}\text { F-CATACCGACGGGATTTAC } \\
\text { R-CAGCAGGTTGTAGCAGAC }\end{array}$ & 49.3 & 209 & $\begin{array}{l}\text { KJOGLUM et } \\
\text { al. (2006), contig } \\
11743\end{array}$ \\
\hline IL- $1 \beta$ & $\begin{array}{l}\text { F-GTGACACTGACTGGAGGAA } \\
\text { R-AGTTTGGGCAAGGAAGA }\end{array}$ & 54.0 & 164 & n.s., s.d. \\
\hline IL- 6 & $\begin{array}{l}\text { F-GGACCGCTTTGAAACTCT } \\
\text { R-GCTCCCTGTAACGCTTGT }\end{array}$ & 54.3 & 212 & $\begin{array}{l}\text { KJOGLUM et } \\
\text { al. (2006), contig } \\
88018\end{array}$ \\
\hline TNF- $\alpha$ & $\begin{array}{l}\text { F-CCAGGCTTTCACTTCAGG } \\
\text { R-GCCATAGGAATCGGAGTAG }\end{array}$ & 51.6 & 181 & KAR et al. (2013) \\
\hline IL- 15 & $\begin{array}{l}\text { F-ACCAACAATCTCGCTTTCG } \\
\text { R-GTTCAACGGGCATTCCAT }\end{array}$ & 52.0 & 154 & DAS et al. (2014) \\
\hline MHCI & $\begin{array}{l}\text { F-GAATGGAGACAAACGCAAAGA } \\
\text { R-TCCAGCATAGGCAAGATGAG }\end{array}$ & 49.8 & 71 & $\begin{array}{l}\text { KJOGLUM et } \\
\text { al. (2006), contig } \\
55372\end{array}$ \\
\hline MHCII & $\begin{array}{l}\text { F-TTTACAAGAGCCCACCAG } \\
\text { R-TTCAGATAAGCGAACACG }\end{array}$ & 55.3 & 229 & $\begin{array}{l}\text { KJOGLUM et } \\
\text { al. (2006), contig } \\
88088\end{array}$ \\
\hline$\beta$-actin & $\begin{array}{l}\text { F-TTGGCAATGAGAGGTTCAGGT } \\
\text { R-TTGGCATACAGGTCCTTACGG }\end{array}$ & 56.0 & 139 & $\begin{array}{l}\text { ROBINSON et al. } \\
(2012)\end{array}$ \\
\hline
\end{tabular}

For qPCR, primer efficiency was checked by serial dilution of the reference cDNA. Quantitative PCR was carried out using the Light Cycler 480 SYBR Green I master mix (Roche, Germany) as described previously (SAHOO et al., 2013). The quantification cycle $(\mathrm{Cq})$ values for each gene were calculated using a second derivative maximum method for absolute quantification analysis, using Light Cycler 480 software. The fold differences were calculated by the $2^{-\Delta \Delta C q}$ method (LIVAK and SCHMITTGEN, 2001). For the gene expression study, the mean value of samples at $0 \mathrm{~h}$ was considered as the calibrator, and that $\Delta \mathrm{Cq}$ value (average $\mathrm{Cq}$ of sample - average $\mathrm{Cq}$ of $\beta$-actin) was 
subtracted from the $\Delta \mathrm{Cq}$ of each sample to get $\Delta \Delta \mathrm{Cq}$. The fold expression of each sample relative to the calibrator was calculated as $2^{-\Delta \Delta C q}$. The average fold expression of each group (in triplicate) was derived at each time point and presented as mean \pm SE. Any significant difference between the groups at each time period was analyzed by One-way ANOVA (SPSS software version 18) followed by Duncan's multiple range test $(\mathrm{P} \leq 0.05$, statistically significant).

\section{Results}

A significantly higher level of IgM transcripts was detected in groups E and F just prior to the challenge. Interestingly, these two groups also showed a higher IgM level up to $24 \mathrm{~h}$ post-challenge (hpc). At $48 \mathrm{hpc}$, the antibody level was up-regulated in all four vaccinated groups except groups A and B (both controls). IgM levels remained higher in groups E and F even at 72 and 120 hpc (Fig. 1).

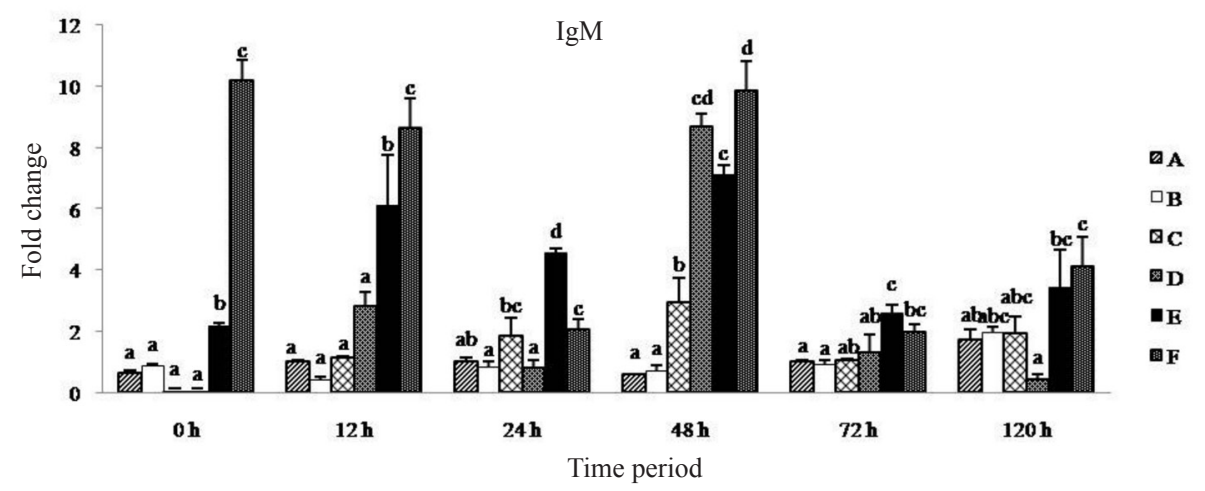

Fig. 1. Variations in expression patterns in IgM in the anterior kidney of different groups at different time periods following challenge with $A$. hydrophila. Bars represent mean \pm SE. Mean values bearing the same superscripts are statistically not different, $\mathrm{P} \leq 0.05$. Group $\mathrm{A}$ - control, group B - injected with PBS-MO, group C - injected with PBS-MO-FKC, group D - injected with PBS-MO-FKC-modified adjuvant, group E - injected with PBS-MO-OmpR and group F - injected with PBS-MO-OmpR-modified adjuvant. Mean values bearing same superscripts (above the bars) are statistically not different, $\mathrm{P} \leq 0.05$.

Before the challenge, a similar pattern of C3 expression was noticed in all groups. An increase in $\mathrm{C} 3$ expression was noted from the initial periods post-challenge, with a relatively higher expression in groups D and F at $12 \mathrm{~h}$. At $24 \mathrm{~h}$, the expression of C3 was higher in groups $\mathrm{D}, \mathrm{E}$ and $\mathrm{F}$, with group $\mathrm{F}$ showing the highest expression of the three 
groups. Subsequently, the $\mathrm{C} 3$ level declined in all groups except group F, which continued to show increased C3 levels even at later intervals (Fig. 2).

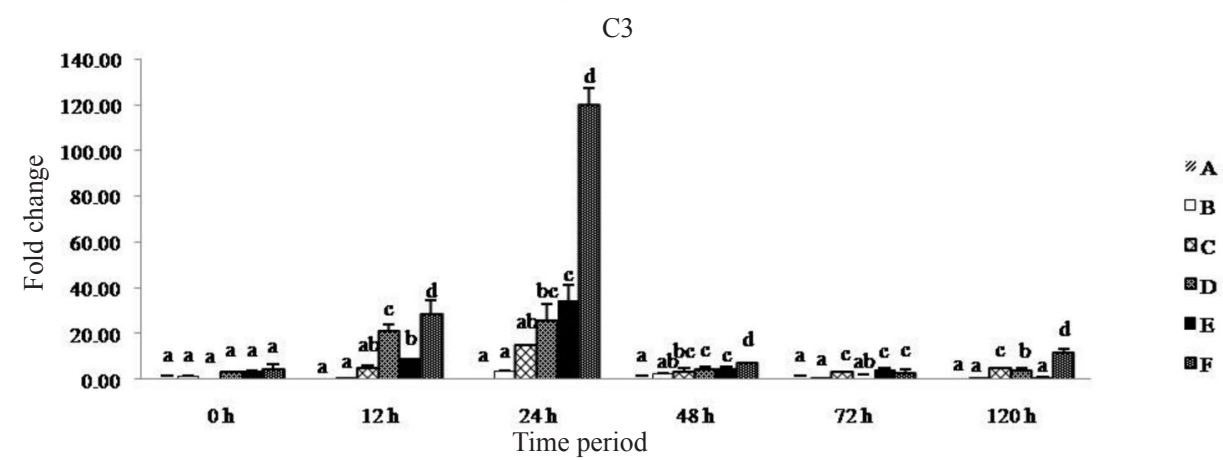

Fig. 2. Variations in expression patterns in $\mathrm{C} 3$ in the anterior kidney of different groups at different time periods following challenge with $A$. hydrophila. Bars represent mean \pm SE. Mean values bearing the same superscripts are statistically not different, $\mathrm{P} \leq 0.05$. Group $\mathrm{A}$ - control, group B - injected with PBS - MO, group C - injected with PBS - MO - FKC, group D - injected with PBS - MO - FKC - modified adjuvant, group E - injected with PBS - MO - OmpR and group $\mathrm{F}$ - injected with PBS-MO-OmpR-modified adjuvant. Mean values bearing same superscripts (above the bars) are statistically not different, $\mathrm{P} \leq 0.05$.

The group of pro-inflammatory cytokines which play major role during bacterial infection were analyzed for changes in their expression profile in the different groups. Before the challenge, no difference was found in the expression levels of IL- 6 and TNF- $\alpha$, whereas IL-15 expression was higher in groups D, E and F in comparison to groups A, B and $\mathrm{C}$. In the case of IL-1 $\beta$, the immunized groups showed an up-regulated expression in comparison to the control, with the highest expression observed in group F (Fig. 3). At $12 \mathrm{hpc}$, IL-1 $\beta$ expression was significantly higher in groups $\mathrm{E}$ and F. At $48 \mathrm{hpc}$, group F showed the highest levels of IL-1 $\beta$, whereas at $72 \mathrm{~h}$ no difference was noted between the various groups. Surprisingly, at $120 \mathrm{hpc}$, group D fish showed the highest expression of IL-1 $\beta$.

An increased expression of IL-6 was found in groups C, D, E and F up to $72 \mathrm{~h}$ after the challenge (except at $48 \mathrm{~h}$, when group $\mathrm{C}$ showed the basal level of IL-6 expression). At $12 \mathrm{hpc}$, group C showed the highest level of IL-6, whereas at subsequent time points, it was highest in group $\mathrm{F}$, followed by groups $\mathrm{D}$ and $\mathrm{E}$. There was a significant decline in IL-6 expression in all the experimental groups at $120 \mathrm{~h}$, except in group F (Fig. 4). 
P. Dash et al.: Post-challenge immune response in rOmpR vaccinated rohu

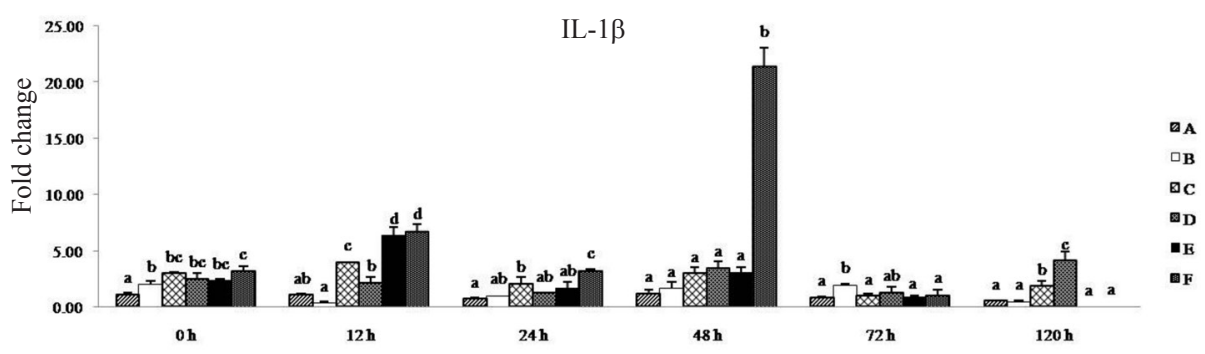

Time period

Fig. 3. Variations in expression patterns in IL-1 $\beta$ in the anterior kidney of different groups at different time periods following challenge with A. hydrophila. Bars represent mean \pm SE. Mean values bearing the same superscripts are statistically not different, $\mathrm{P} \leq 0.05$. Group A-control, group B- injected with PBS-MO, group C- injected with PBS-MO-FKC, group D- injected with PBS-MO-FKC-modified adjuvant, group E-injected with PBS-MO-OmpR and group F- injected with PBS-MO-OmpR-modified adjuvant. Mean values bearing same superscripts (above the bars) are statistically not different, $\mathrm{P} \leq 0.05$.

An up-regulation in TNF- $\alpha$ was evident in all the immunized groups at $12 \mathrm{hpc}$. At $24 \mathrm{~h}$, the level of the TNF- $\alpha$ transcripts was up-regulated in groups D, E and F, whereas at 48 and $120 \mathrm{~h}$, it was the highest in group F animals (Fig. 5). The higher expression of IL-15 was marked in immunized groups D, E and F prior to the challenge, but only group $\mathrm{C}$ animals showed an increased expression of this gene at $120 \mathrm{~h}$ after the challenge with A. hydrophila (Fig. 6).

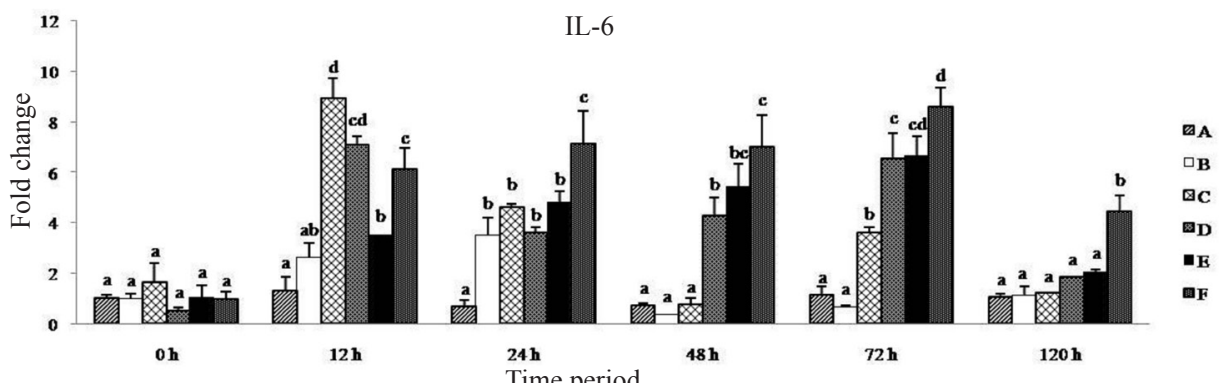

Fig. 4. Variations in expression patterns in IL-6 in the anterior kidney of different groups at different time periods following challenge with A. hydrophila. Bars represent mean \pm SE. Mean values bearing the same superscripts are statistically not different, $\mathrm{P} \leq 0.05$. Group A - control, group B - injected with PBS - MO, group C - injected with PBS - MO - FKC, group D - injected with PBS - MO - FKC - modified adjuvant, group E - injected with PBS - MO - OmpR and group $\mathrm{F}$ - injected with PBS-MO-OmpR-modified adjuvant. Mean values bearing same superscripts (above the bars) are statistically not different, $\mathrm{P} \leq 0.05$. 


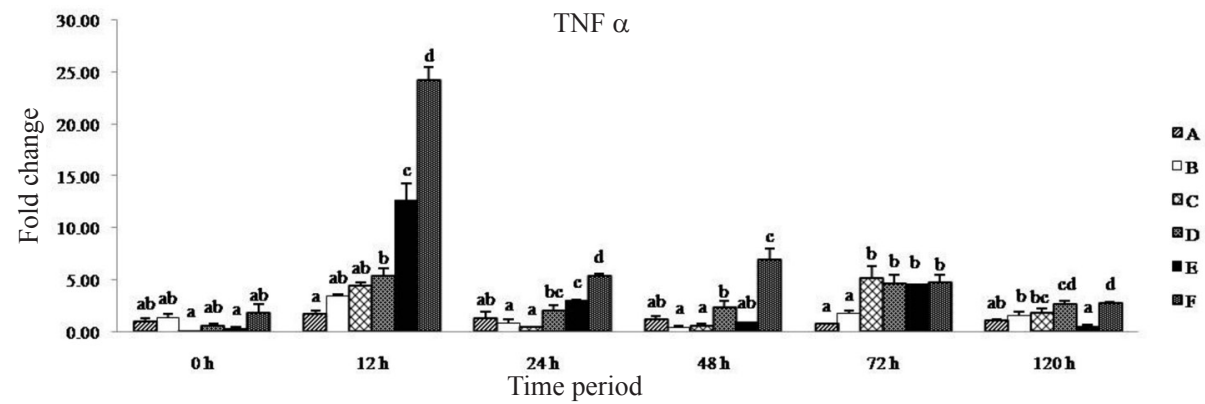

Fig. 5. Variations in expression patterns in TNF $\alpha$ in the anterior kidney of different groups at different time periods following challenge with $A$. hydrophila. Bars represent mean \pm SE. Mean values bearing the same superscripts are statistically not different, $\mathrm{P} \leq 0.05$. Group A - control, group B - injected with PBS - MO, group C - injected with PBS - MO - FKC, group D - injected with PBS - MO - FKC - modified adjuvant, group E - injected with PBS - MO - OmpR and group F - injected with PBS-MO-OmpR-modified adjuvant. Mean values bearing same superscripts (above the bars) are statistically not different, $\mathrm{P} \leq 0.05$.

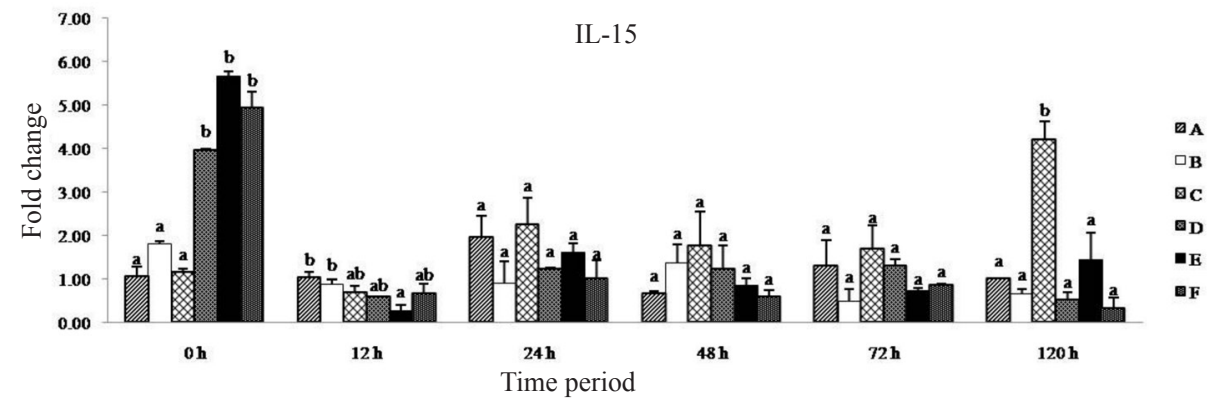

Fig. 6. Variations in expression patterns in IL-15 in the anterior kidney of different groups at different time periods following challenge with $A$. hydrophila. Bars represent mean $\pm \mathrm{SE}$. Mean values bearing the same superscripts are statistically not different, $\mathrm{P} \leq 0.05$. Group $\mathrm{A}$ - control, group B - injected with PBS - MO, group C - injected with PBS - MO - FKC, group D - injected with PBS - MO - FKC - modified adjuvant, group E - injected with PBS - MO - OmpR and group F - injected with PBS-MO-OmpR-modified adjuvant. Mean values bearing same superscripts (above the bars) are statistically not different, $\mathrm{P} \leq 0.05$. 


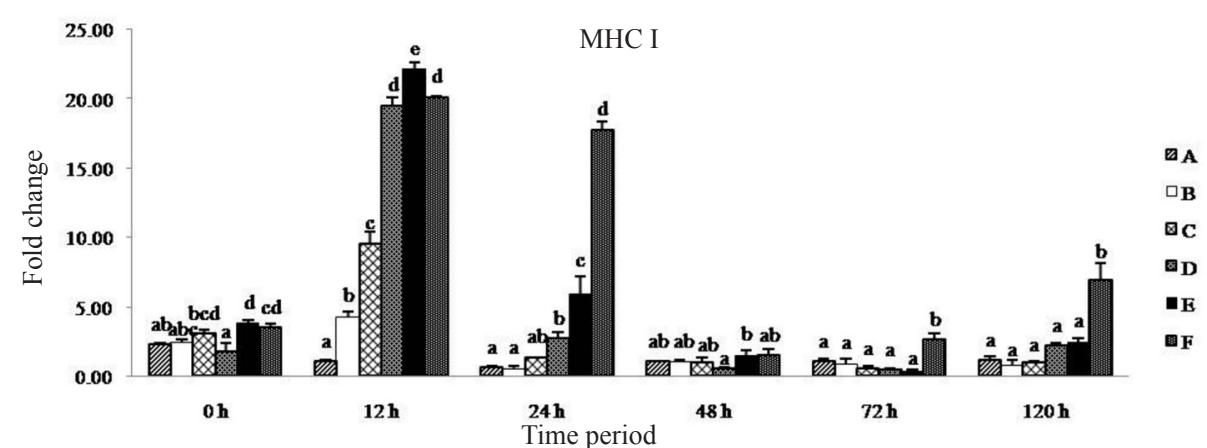

Fig. 7. Variations in expression patterns in MHC I in the anterior kidney of different groups at different time periods following challenge with $A$. hydrophila. Bars represent mean \pm SE. Mean values bearing the same superscripts are statistically not different, $\mathrm{P} \leq 0.05$. Group A - control, group B - injected with PBS - MO, group C - injected with PBS - MO - FKC, group D - injected with PBS - MO - FKC - modified adjuvant, group E - injected with PBS - MO - OmpR and group F - injected with PBS-MO-OmpR-modified adjuvant. Mean values bearing same superscripts (above the bars) are statistically not different, $\mathrm{P} \leq 0.05$.

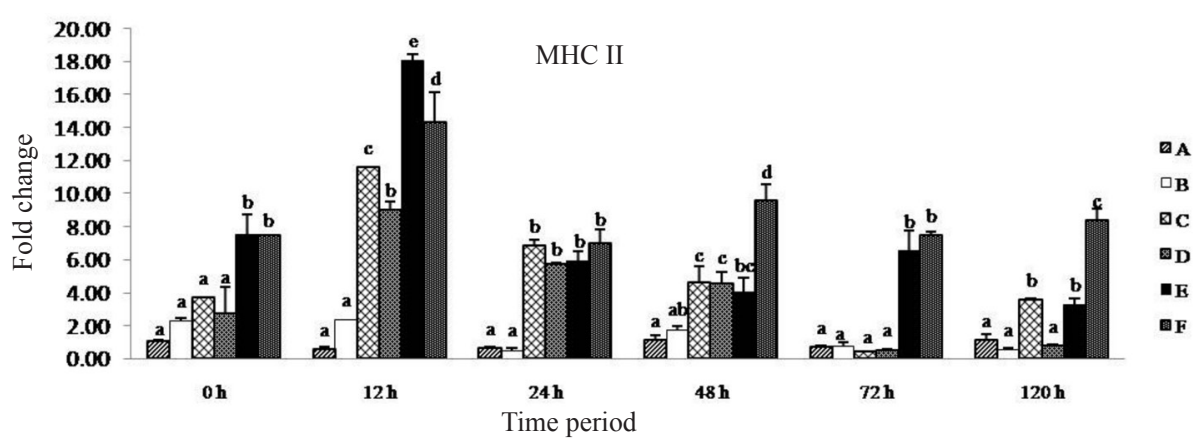

Fig. 8. Variations in expression patterns in MHC II in the anterior kidney of different groups at different time periods following challenge with $A$. hydrophila. Bars represent mean \pm SE. Mean values bearing the same superscripts are statistically not different, $\mathrm{P} \leq 0.05$. Group A-control, group B- injected with PBS-MO, group C- injected with PBS-MO-FKC, group D- injected with PBS-MO-FKC-modified adjuvant, group E-injected with PBS-MO-OmpR and group F- injected with PBS-MO-OmpR-modified adjuvant. Mean values bearing same superscripts (above the bars) are statistically not different, $\mathrm{P} \leq 0.05$.

An induced expression of MHC I and MHC II was found in rOmpR-vaccinated groups $\mathrm{E}$ and $\mathrm{F}$ prior to the challenge (Figs. 7 and 8). Further, at $12 \mathrm{hpc}$, all the immunized groups showed elevated levels of both MHC I and MHC II transcripts, with group E showing the 


\section{P. Dash et al.: Post-challenge immune response in rOmpR vaccinated rohu}

highest levels in both cases. At $24 \mathrm{hpc}$, the MHC I level was higher in groups E and F, and at later time points the level started to decrease in all groups. However, at 72 and $120 \mathrm{hpc}$, the fish in group F showed an increased expression of MHC I. In the case of MHC II, the level continued to be increased after $12 \mathrm{hpc}$, with a varying degree of expression among the experimental groups. At 24 and $48 \mathrm{hpc}$, all the immunized groups showed high levels of MHC II, whereas at $72 \mathrm{~h}$, it only remained higher in groups E and F. An up-regulated $\mathrm{MHC}$ II was found in group $\mathrm{F}$ at all time points post-challenge.

\section{Discussion}

To investigate the immunological mechanism underlying the protection provided by modified adjuvant-based rOmpR vaccine at the transcript level, we studied a suite of immune molecules of various pathways of the immune system which play major role during any immunological insult to the host. Antibody-mediated humoral immunity plays a major role in fish during bacterial infections, such as Vibrio anguillarum, A. hydrophila, Flavobacterium psychrophilum, Streptococcus agalactiae and Streptococcus iniae, and results in increased protection (JIAO et al., 2010). Many researchers have looked at the changes in gene expression in fish, post-vaccination or post-infection, but our knowledge of the post-challenge immune response in vaccinated fish is very limited (HARUN et al., 2011; DAS et al., 2011; MAHAPATRA et al., 2008).

In the present study, the significantly higher IgM level in both rOmpR vaccinated groups indicated the role of humoral immunity provided by the novel antigenic formulations during A. hydrophila infection. A positive correlation has been reported between increased antibody titer against an A-layer protein of A. salmonicida and the survival rate of Atlantic salmon post-infection with the pathogen (LUND et al., 1995). Higher IgM levels in OmpR-modified adjuvant/non-challenged fish point towards a longlived antibody response, along with elevated innate immune effectors, as noticed in this study. The rOmpR component of $A$. hydrophila might be able to mimic the pathogen itself, thus resulting in higher levels of protective antibody, as reflected in the postchallenge survival rate of rOmpR vaccinated groups (DASH et al., 2014). An elevated IgM titer was marked in A. hydrophila resistant common carp families, when challenged with the specific pathogen (ARDO et al., 2010). C3 is considered to be an important antimicrobial weapon of teleosts, which initiates complement mediated opsonization during infection (DAS et al., 2011). Increased C3 levels at an early hour after challenge, as well as at subsequent time points $(24,72$ and $120 \mathrm{hpc})$ in group $\mathrm{F}$ fish, perhaps suggest the immediate activation of the complement cascade in animals injected with this modified adjuvant-rOmpR, which leads to the early clearance of the pathogen by activated phagocytosis/opsonization like activities. Besides these complement molecules, the role of pro-inflammatory cytokines during infection, the key molecules involved in activation and recruitment of leucocytes at the site of inflammation, also needs to be investigated. 


\section{P. Dash et al.: Post-challenge immune response in rOmpR vaccinated rohu}

In most studies, the expression level of pro-inflammatory cytokines was found to be upregulated post-infection (ROJO et al., 2007). In the present study, one of the remarkable changes was found in the expression of some cytokines in animals immunized with modified adjuvant-rOmpR. An increased level of IL- $1 \beta$ and TNF- $\alpha$ in that group, up to 48 hpc, suggests the activation of these cytokines immediately after infection and the drop in their levels later, might reflect a decrease in the bacterial burden or neutralization of the inflammation. Although changes were marked in other immunized groups as well, these were not significant. In contrast to these two cytokines, highly up-regulated IL-6 was evident in all the groups up to $72 \mathrm{hpc}$, except groups A and B, suggesting the early activation of the inflammatory pathway in these groups. In fish that received the modified adjuvant-based rOmpR formulation (group F), the highest expression of IL-1 $\beta$ and IL- 6 at almost all time points post-challenge might be indicative of the good response induced by the vaccine formulation. These cytokines, as the key molecules in initiating inflammation and immune response, activate T cells, B cells, natural killer cells and phagocytic cells (ROJO et al., 2007). A progressive increase in the expression of IL-1 $\beta$ and TNF- $\alpha$ at early time points after bacterial infection, followed by a subsequent decrease, was also reported previously (ROJO et al., 2007). The expression pattern of pro-inflammatory cytokines in the rOmpR-vaccinated groups further proved the antigenic potential of OmpR of $A$. hydrophila in fish. When the vaccinated fish were challenged with $A$. hydrophila, the host immune system functioned more efficiently, as it had had prior exposure to the rOmpR antigen of this bacterium. Additionally, the response was significantly higher in the group that received the modified adjuvant-based vaccine. As IL-15 plays an immunoregulatory role in the cross-talk between specific and innate immunity, we tried to highlight its role during infection in the vaccinated fish. Surprisingly, while its expression was higher in the vaccinated fish before the challenge, no difference was found among the groups at different time points post-challenge, indicating the non-responsiveness of this molecule. However, there are several reports revealing the protection provided by rIL-15 against invading bacterial pathogens (FEHNIGER and CALIGIURI, 2001). The higher MHC II expression in groups that were injected with $\mathrm{rOmpR}$, before the challenge as well as after the challenge suggests a MHC II mediated response/T helper cell response to be more prominent in vaccinated groups. Besides, the level was also found to be increased in the challenged FKC injected groups up to $48 \mathrm{hpc}$, which was expected as the challenge acts as a re-infection with the same pathogen in those groups. An increase in the expression of immune genes was found in fish immunized with bacterial antigens, or during infection (CAIPANG et al., 2008). The initial FKC immunization in these animals might have activated an immune response, which, upon a challenge with the same organism, produced increased MHC molecules. However, the increased MHC I titer in antigen injected groups at early time points post-challenge cannot be ignored. APCs are the connecting link between adaptive and innate immunity. Among them, dendritic cells 


\section{P. Dash et al.: Post-challenge immune response in rOmpR vaccinated rohu}

play a very important role. They stimulate naïve $\mathrm{T}$ cells and present exogenous antigens to MHC I. It has been reported that OmpA of Klebsiella pneumonia, a gram-negative pathogen, elicits MHC I response through dendritic cells (JEANNIN et al., 2000; JEANNIN et al., 2002). An antigen presentation of rOmps also occurs sometimes through the MHC II pathway, as the presentation depends upon the processing of the antigens, i.e. whether it is endogenous or exogenous (VOLAND et al., 2003). In this study, induction of MHC I after the challenge might be due to the involvement of the dendritic cell mediated $\mathrm{CD}^{+} \mathrm{T}$ cell immune response in rOmpR-vaccinated fish. On the other hand, the induced expression of MHC II in rOmpR vaccinated fish at different time points after the challenge suggests activation of both the arms of the antigen presentation. As it is well known that at $\mathrm{CD} 4^{+} \mathrm{T}$ cells are potent inducers of CD $8^{+} \mathrm{T}$ cells, induced expression of both MHC I and MHC II in the rOmpR group animals could be due to the cross-talk between these two molecules for immune clearance of the antigen. As MHC molecules have been found to protect fish during infections, an elevated level could well be correlated with the potential of rOmpR/ rOmpR-modified adjuvant formulation against $A$. hydrophila infection (KJOGLUM et al., 2006). Although some vaccination studies have focused on the MHC I pathway of antigen presentation, studies on the downstream molecules involved in the process need to be further explored (YANG et al., 2013). The increased expression of some genes, viz. IgM, IL-15 and MHC II, in vaccinated fish before the challenge, may also help the host to fight against any type of infection.

\section{Conclusion}

The study showed the immediate onset of pro-inflammatory cytokines in vaccinated groups post-challenge, with the activation of humoral immunity from early time points onwards. It further confirmed that both arms (humoral and cell mediated) of immunity can act simultaneously, or share the responsibility at different stages of infection, for early clearance of the pathogen. The modified adjuvant must play some role in boosting the immunity since the response was stronger in the modified adjuvant treated groups alone. Further studies on this modified vaccine formulation are needed for its field application, which may help in minimizing the loss caused by this pathogen to the aquaculture industry.

\section{Conflicts of interest}

All authors declare that they have no conflicts of interest related to the work presented in this article.

\footnotetext{
Acknowledgements

The support provided by the Department of Biotechnology, New Delhi, India, under the Indo-Norway Vaccine Platform Project for carrying out this work, is duly acknowledged. The authors wish to thank the Director, Central Institute of Freshwater Aquaculture, Kausalyaganga, Bhubaneswar, India, for providing the necessary facilities during this study.
} 
P. Dash et al.: Post-challenge immune response in rOmpR vaccinated rohu

\section{References}

ARDÓ, L., Z. JENEY, A. ADAMS, G. JENEY (2010): Immune responses of resistant and sensitive common carp families following experimental challenge with Aeromonas hydrophila. Fish Shellfish Immunol. 29, 111-116.

CAIPANG, C. M. A., N. HYNES, J. PUANGKAEW, M. F. BRINCHMANN, V. KIRON (2008): Intraperitoneal vaccination of Atlantic cod, Gadus morhua with heat-killed Listonella anguillarum enhances serum antibacterial activity and expression of immune genes. Fish Shellfish Immunol. 24, 314-322.

CUESTA, A., C. TAFALLA (2009): Transcription of immune genes upon challenge with viral hemorrhagic septicemia virus (VHSV) in DNA vaccinated rainbow trout (Oncorhynchus mykiss). Vaccine 27, 280-289.

DAS, A., P. K. SAHOO, B. R. MOHANTY, J. K. JENA (2011): Pathophysiology of experimental Aeromonas hydrophila infection in Puntius sarana: Early changes in blood and aspects of the innate immune-related gene expression in survivors. Vet. Immunol. Immunopathol. 14, $2207-$ 2218.

DAS, S., A. MOHAPATRA, B. KAR, P. K. SAHOO (2014): Molecular characterization of interleukin 15 mRNA from rohu, Labeo rohita (Hamilton): its prominent role during parasite infection as indicated from infection studies. Fish Shellfish Immunol. DOI: 10.1016/j. fsi.2014.12.002

DASH, P., P. K. SAHOO, P. K. GUPTA, L. C. GARG, A. DIXIT (2014): Immune responses and protective efficacy of recombinant outer membrane protein $\mathrm{R}(\mathrm{rOmpR})$-based vaccine of Aeromonas hydrophila with a modified adjuvant formulation in rohu (Labeo rohita). Fish Shellfish Immunol. 39, 512-523.

FEHNIGER, T. A., M. A. CALIGIURI (2001): Interleukin 15: biology and relevance to human disease. Blood 97, 14-32.

HARUN, N. O., T. WANG, C. J. SECOMBES (2011): Gene expression profiling in naïve and vaccinated rainbow trout after Yersinia ruckeri infection: Insights into the mechanisms of protection seen in vaccinated fish. Vaccine 29, 4388-4399.

JEANNIN, P., G. MAGistrelli, L. GOETSCH, J. F. HAEUW, N. THIEBLEMONT, J. Y. BONNEFOY, Y. DELNESTE (2002): Outer membrane protein A (OmpA): a new pathogenassociated molecular pattern that interacts with antigen presenting cells-impact on vaccine strategies. Vaccines 20, Suppl. 4, A23-A27.

JEANNIN, P., T. RENNO, L. GOETSCH, I. MICONNET, J. AUBRY, Y. DELNESTE, N. HERBAULT, T. BAUSSANT, G. MAGISTRELLI, C. SOULAS, P. ROMERO, J. CEROTTINI, J. BONNEFOY (2000): OmpA targets dendritic cells, induces their maturation and delivers antigen into the MHC class I presentation pathway. Nature Immunol. 1, 502-509.

JIAO, X., S. CHENGA, Y. HUA, L. SUN (2010): Comparative study of the effects of aluminium adjuvants and Freund's incomplete adjuvant on the immune response to an Edwardsiella tarda major antigen. Vaccine 28, 1832-1837. 


\section{P. Dash et al.: Post-challenge immune response in rOmpR vaccinated rohu}

KAR, B., J. MOHANTY, K. P. HEMAPRASANTH, P. K. SAHOO (2013): The immune response in rohu, Labeo rohita (Actinopterygii: Cyprinidae) to Argulus siamensis (Branchiura: Argulidae) infection: kinetics of immune gene expression and innate immune response. Aquaculture Res. DOI:10.1111/are.12279.

KJOGLUM, S., S. LARSEN, H. G. BAKKE, U. GRIMHOLT (2006): How specific MHC class I and class II combinations affect disease resistance against infectious salmon anaemia in Atlantic salmon (Salmo salar). Fish Shellfish Immunol. 21, 431-441.

LIVAK, K. J., T. D. SCHMITTGEN (2001): Analysis of relative gene expression data using real time quantitative PCR and the 2 (T) (- Delta Delta C) method. Methods 25, 402-408.

LUND, T., J. CHIAYVAREESAJJA, H. J. S. LARSEN, K. H. RØ (1995): Antibody response after immunization as a potential indirect marker for improved resistance against furunculosis. Fish Shellfish Immunol. 5, 109-119.

MAHAPATRA, K. D., B. GJERDE, P. K. SAHOO, J. N. SAHA, A. BARAT, M. SAHOO, B. R. MOHANTY, J. ODEGARD, M. RYE, R. SALTE (2008). Genetic variations in survival of rohu (Labeo rohita, Hamilton) after Aeromonas hydrophila infection in challenge tests. Aquaculture 279, 29-34.

MOHANTY, B. R., J. MISHRA, S. DAS, J. K. JENA, P. K. SAHOO (2008): An outbreak of aeromoniasis in an organized composite carp culture farm in India: Experimental pathogenicity and antibiogram study. J. Aqua. 16, 27-37.

MU, X., J. W. PRIDGEON, P. H. KLESIUS (2011): Transcriptional profiles of multiple genes in the anterior kidney of channel catfish vaccinated with an attenuated Aeromonas hydrophila. Fish Shellfish Immunol. 31, 1162-1172.

POOBALANE, S., K. D. THOMPSON, L. ARDO, N. VERJAN, H. HAN, G. JENEY, I. HIRONO, T. AOKI, A. ADAMS (2010): Production and efficacy of an Aeromonas hydrophila recombinant S-layer protein vaccine for fish. Vaccine 28, 3540-3547.

POPPE, T. T., O. BRECK (1997): Pathology of Atlantic salmon Salmo salar intraperitoneally immunized with oil-adjuvanted vaccine. A case report. Dis. Aquat. Org. 29, 219-226.

ROBINSON, N., P. K. SAHOO, M. BARANSKI, K. D. MAHAPATRA, J. N. SAHA, S. DAS, Y. MISHRA, P. DAS, H. K. BARMAN, A. E. EKNATH (2012): Expressed sequences and polymorphisms in rohu carp (Labeo rohita Hamilton) revealed by mRNA-seq. Mar. Biotechnol. 14, 620-633.

ROJO, I., O. S. MARTI'NEZ DE ILARDUYA, A. ESTONBA, M. PARDO (2007): Innate immune gene expression in individual zebrafish after Listonella anguillarum inoculation. Fish Shellfish Immunol. 23, 1285-1293.

SAHOO, P. K., S. DAS, K. D. MAHAPATRA, J. N. SAHA, M. BARANSKI, J. ØDEGÅRD, N. ROBINSON (2013): Characterization of the ceruloplasmin gene and its potential role as an indirect marker for selection to Aeromonas hydrophila resistance in rohu, Labeo rohita. Fish Shellfish Immunol. 34, 1325-1334. 
P. Dash et al.: Post-challenge immune response in rOmpR vaccinated rohu

VOLAND, P., N. HAFSI, M. ZEITNER, S. LAFORSCH, H. WAGNER, C. PRINZ (2003): Antigenic properties of HpaA and Omp18, two outer membrane proteins of Helicobacter pylori. Infect. Immun. 71, 3837-3843.

YANG, D., Q. LIU, C. NI, S. LI, H. WU, Q. WANG, J. XIAO, Y. JHANG (2013): Gene expression profiling in live attenuated Edwardsiella tarda vaccine immunized and challenged zebrafish: Insights into the basic mechanisms of protection seen in immunized fish. Dev. Comp. Immunol. 40, 132-141.

YIN, G., L. ARDO, K. D. THOMPSON, A. ADAMS, Z. JENEY, G. JENEY (2009): Chinese herbs (Astragalus radix and Ganoderma lucidum) enhance immune response of carp, Cyprinus carpio and protection against Aeromonas hydrophila. Fish Shellfish Immunol. 26, 140-145.

ZHOU, X., Q. GUO, H. DAI (2008): Identification of differentially expressed immune-relevant genes in Chinese soft-shelled turtle (Trionyx sinensis) infected with Aeromonas hydrophila. Vet. Immunol. Immunopathol. 125, 82-91.

Received: 30 April 2016

Accepted: 23 March 2017

\section{DASH, P., S. K. YADAV, L. C. GARG, A. DIXIT, P. K. SAHOO: Ekspresija gena za imunološki odgovor nakon izazivačke infekcije u indijskih šarana rohu (Labeo rohita) cijepljenih modificiranom formulacijom proteina $R$ vanjske membrane bakterije Aeromonas hydrophila. Vet arhiv 87, 607-622, 2017. SAŽETAK}

Iako su cijepljenje i istraživanja nakon cijepljenja znatno dobila na važnosti u borbi protiv bolesti u akvakulturi, malo se zna o mehanizmu imunološke zaštite u cijepljenih riba nakon izazivačke infekcije. U ovom se istraživanju pokušalo rasvijetliti mehanizam zaštite nakon cijepljenja modificiranim cjepivom pripravljenim od rekombinantnog proteina $\mathrm{R}(\mathrm{rOmpR})$ vezanog na adjuvans u vrste Labeo rohita (za Indiju važne vrste šarana) i izazivačke infekcije vrstom Aeromonas hydrophila. U tu svrhu analizirana je ekspresija niza imunosnih molekula (IgM, faktor 3 komplementa, interleukin $1 \beta$, interleukin 6, faktor tumorske nekroze $\alpha$, interleukin 15, MHC I and MHC II) u bubrežnim tkivima cijepljenih riba 0, 12, 24, 48, 72 i 120 h nakon izazivačke infekcije. Više razine transkripata IgM, MHC I i MHC II bile su očite u skupina cijepljenih OmpR-om s mineralnim uljem kao adjuvansom i modificiranim OmpR-om s mineralnim uljem u različitim vremenskim razmacima nakon izazivačke infekcije kao i onih koje nisu bile podvrgnute izazivačkoj infekciji. Rana pojava proupalnih citokina i ekspresije većine imunosnih gena bila je više izražena u cijepljenih riba u različitim vremenskim točkama nakon izazivačke infekcije što upućuje na bolji imunosni odgovor u tih riba. Ovo istraživanje naznačuje aktivaciju i humoralne i stanične imunosti u cijepljenih rohu riba nakon izazivačke infekcije bakterijom $A$. hydrophila.

Ključne riječi: adjuvans, Aeromonas hydrophila, genska ekspresija, izazivačka infekcija, Labeo rohita 